Узагальнюючи зазначене вище, комплексом педагогічних умов ефективного формування готовності майбутніх вихователів до роботи 3 дітьми 3 функціональними порушеннями ОРА $\epsilon$ необхідна й достатня сукупність взаємопов'язаних заходів навчально-виховного процесу, дотримання яких забезпечує досягнення студентами високого рівня готовності до даного виду професійної діяльності.

Отже, основними педагогічними умовами формування готовності майбутніх вихователів до роботи 3 дітьми з функціональними порушеннями ОРА ми визначили: рівень мотиваційної і професійно-педагогічної спрямованості до діяльності вихователя; формування теоретико-методичних знань щодо розуміння сутності та механізмів роботи 3 дітьми з функціональними порушеннями ОРА. Внесення до варіативної частини робочих навчальних планів підготовки бакалаврів спецкурсу «Профілактика та корекція функціональних порушень опорно-рухового апарату у дітей дошкільного віку»; оптимальне поєднання змісту, форм та методів навчання задля забезпечення цілісності системи фахової підготовки; застосування спеціального обладнання у процесі опанування методиками діагностики та корекції функціональних порушень ОРА у дошкільників; внесення до змісту педагогічної практики завдань, що формують у студентів уміння здійснювати профілактично-корегувальну роботу 3 дітьми, які мають функціональні порушення ОРА.

Запропоновані педагогічні умови перебувають у тісному взаємозв'язку. Їх дотримання в навчальній практиці вишу сприятиме формуванню готовності майбутніх вихователів до роботи 3 дітьми, які мають функціональні порушення ОРА, зміст яких визначається цілями, задачами, характером майбутньої фахової діяльності та становлять єдність теоретичної, практичної та мотиваційної готовності випускника навчального закладу здійснювати професійну діяльність. Подальшого дослідження потребує детальна характеристика виокремлених педагогічних умов.

\title{
Література
}

1. Кузьмина Н. В. Профессионализм деятельности преподавателя и мастера производственного обучения профтехучилища / Н. М. Кузьмина. - М. : Высшая школа, 1989. 179 с. 2. Посталюк Н. Ю. Концептуальные основы организации мониторинга региональных систем начального профессионального образования / Н. Ю. Посталюк, С. Ю. Алашеев // Стандарты и мониторинг в образовании. - 2006. - С. 37-43. 3. Философский энциклопедический словарь / Е.Ф. Губский, Г. В. Кораблева, В. А. Лутченко - М. : ИНФРА-М, 2006. - 576 с. 4. Філософський енциклопедичний словник / за ред. В. І. Шинкарука. - К. : Абрикос, 2002. - 392 с. 5. Якуба Ю. А. Связь теоретического и производственного обучения в средних профтехучилищах / Ю. А. Якуба. - М. : Высшая школа, 1986. - 56 с.

УДК [378: 338.48](470+571)

Г. П. Щука, докторант,

Інститут торгівлі, обслуговуючих технологій та туризму, ДВНЗ «Луганський національний університет імені Тараса Шевченка»

\section{ЗМІСТ ПІДГОТОВКИ ФАХІВЦІВ СФЕРИ ТУРИЗМУ У ВИЩИХ НАВЧАЛЬНИХ ЗАКЛАДАХ УКРАЇНИ ТА РОСІЙСЬКОЇ ФЕДЕРАЦЇ: ПОРІВНЯЛЬНИЙ АНАЛІЗ}

Щука Г. П. Зміст підготовки фахівців сфери туризму у вищих навчальних закладах України та Російської Федерації: порівняльний аналіз.

У статті на основі зіставлення, порівняння, узагальнення вітчизняних та російських стандартів підготовки бакалаврів та магістрів туризму визначається спільне та особливе у змісті підготовки фахівців сфери туризму цього рівня, розглядаються можливості запровадження окремих елементів досвіду російських колег у діяльність вітчизняних навчальних закладів, які реалізують напрям підготовки «Туризм».

Ключові слова: галузеві стандарти, підготовка кадрів, професійна туристська освіта, туризм. 
Щука Г.П. Содержание подготовки специалистов сферы туризма в высших учебных заведениях Украины и Российской Федерации: сравнительный анализ.

В статье на основе сопоставления, сравнения, обобщения отечественных и российских стандартов подготовки бакалавров и магистров туризма определяется общее и особенное в содержании подготовки специалистов сферы туризма этого уровня, рассматриваются возможности внедрения отдельных элементов опыта российских коллег в деятельность отечественных учебных заведений, реализующих направление подготовки «Туризм».

Ключевые слова: отраслевые стандарты, подготовка кадров, профессиональное туристское образование, туризм.

Shchuka G. P. The content of training of tourism specialists in higher educational institutions of the Russian Federation and Ukraine: comparative analysis.

In the article on the basis of the comparison, comparison, generalization of domestic and Russian standards for the preparation of bachelors and masters of tourism is determined by the General and specific in the content of the training of tourism specialists of this level, perspectives of introduction of separate elements of the experience of the Russian colleagues in the activity of the domestic educational institutions, implementing the training direction «Tourism».

Key words: industry standards, training, and professional tourism education, tourism.

У сучасних умовах туризм має важливе значення для розвитку економіки та соціальної сфери будь-якої країни. Водночас з формуванням туризму як самостійної галузі економіки відбувається становлення національної системи професійної туристської освіти. Професійна освіта в туризмі охоплює цілий пласт складних і різнопланових проблем, поміж яких - бажання наближення до практики, необхідність урахування суспільних та індивідуальних потреб, забезпечення саморозвитку й самореалізації майбутніх фахівців, підвищення їх ролі як у навчальному процесі, так i, 3 часом, у функціонуванні туристського підприємства та низка інших.

Для того, щоб правильно організувати процес підготовки фахівців сфери туризму і забезпечити вітчизняний туристський ринок висококваліфікованими кадрами, необхідно правильно організувати систему професійної туристської освіти. Відтак важливим є визначення мети підготовки та моделі фахівця, якого ми бажаємо отримати. Тому корисно знати, як організовується система професійної туристської освіти в інших країнах, які цілі вони ставлять, до яких результатів прагнуть.

Варто зауважити, що вітчизняні туризмологи активно вивчають досвід інших країн. На сучасному етапі ми маємо грунтовні роботи Л. Кнодель, Л. Польової, Л. Чорної, В. Федорченка, Т. Сокол та інших дослідників із проблем підготовки фахівців сфери туризму у країнах Європи та Північної Америки. Звернемося до досвіду підготовки фахівців Російської Федерації, оскільки вони мали подібні до наших стартові умови і розв'язують аналогічні проблеми.

Mema cmammi - порівняти зміст підготовки фахівців сфери туризму у вищих навчальних закладах України та Російської Федерації.

У Російській Федерації з 2011 р. здійснюється підготовка фахівців сфери туризму за напрямом підготовки 100400 Туризм за двома ступенями: бакалавр та магістр. Після 4 років навчання (240 кредитів) випускникам бакалавріату присвоюється кваліфікація бакалавр туризму. Термін навчання в магістратурі складає 2 роки (120 кредитів), випускники отримують диплом магістра туризму.

В Україні підготовка фахівців сфери туризму здійснюється за напрямом підготовки 140103 Туризм за трьома ступенями: бакалавр, спеціаліст та магістр. Після 4 років навчання (240 кредитів) випускникам бакалаврату присвоюється кваліфікація бакалавр із туризму, фахівець туристичного обслуговування. Термін навчання на ОКР «спеціаліст» триває 1 рік (60 кредитів), по закінченню випускники отримують кваліфікацію спеціаліст iз туризмознавства. Термін навчання в магістратурі складає 1,5 роки (90 кредитів), випускники набувають кваліфікації магістра 3 туризмознавства, туризмознавця, екскурсознавця. 
Підготовка бакалаврів та магістрів у Росії здійснюється відповідно до Федеральних державних освітніх стандартів вищої професійної освіти (далі ФДОС ВПО-Б [4] та ФДОС ВПО-М [5]), уведених у 2009 р. Підготовка бакалаврів та магістрів в Україні здійснюється відповідно до Галузевих стандартів вищої освіти України (далі ГСВО-Б [1] та ГСВО-М [2]), введених у 2010 р. Незважаючи на той факт, що названі стандарти розроблялися та вводилися в дію майже одночасно, вони суттєво різняться.

ФДОС ВПО-Б та ФДОС ВПО-М відносяться до стандартів третього покоління і мають вісім розділів: сферу використання; скорочення, які використовуються; характеристика напряму підготовки; характеристика професійної діяльності; вимоги до результатів засвоєння основної освітньої програми (ООП); вимоги до структури ООП; вимоги до умов реалізації ООП; оцінка якості засвоєння ООП. Структура стандарту дозволяє простежити процес побудови моделі підготовки фахівця сфери туризму: визначення сфери професійної діяльності фахівця - об’єкти професійної діяльності - види професійної діяльності - задачі професійної діяльності - загальнокультурні та професійні компетенції - структура ООП (у т.ч. знання, вміння, навики з конкретного циклу дисциплін) - вимоги до умов реалізації ООП - оцінювання якості засвоєння ООП.

ГСВО-Б та ГСВО-М містять Освітньо-професійні програми (ОПП) підготовки та Засоби діагностики якості вищої освіти. Донині Освітньо-кваліфікаційні характеристики (OKX) бакалавра та магістра не розроблено. Тому ми не можемо напевно окреслити сферу професійної діяльності вітчизняних фахівців сфери туризму і визначити, до яких видів діяльності готують студентів. Отже, загальне та особливе в підготовці фахівців сфери туризму в Україні та Росії ми визначаємо на основі зівставлення змісту підготовки. Розпочнемо з аналізу змісту підготовки бакалаврів.

Підготовка бакалаврів у Росії здійснюється відповідно до одного зі встановлених державним стандартом профілів:

- Технологія і організація туроператорських і турагентских послуг;

- Технологія і організація екскурсійних послуг;

- Технологія і організація транспортних послуг;

- Технологія і організація спортивно-оздоровчих послуг;

- Технологія і організація розваг.

Навчальний заклад обирає профіль підготовки залежно від потреб регіонального туристського ринку i власних можливостей. Профіль підготовки визначає зміст варіативної частини ООП підготовки бакалавра. В Україні майбутні бакалаври з туризму готуються за єдиною програмою, зміст варіативної частини визначається довільно.

Розподіл змісту підготовки бакалаврів відбувається за трьома циклами, назви яких у стандартах відрізняються незначною мірою(див. табл. 1):

Зіставлення назв циклів ОПП України й ООП Російської Федерації

Таблиия 1

\begin{tabular}{|l|l|l|}
\hline Номер циклу & \multicolumn{1}{|c|}{ ГСВО-Б } & \multicolumn{1}{|c|}{ ФОС ВПО-Б } \\
\hline Перший & Цикл соціально-гуманітарної підготовки & $\begin{array}{l}\text { Гуманітарний, соціальний та } \\
\text { економічний цикл }\end{array}$ \\
\hline Другий & $\begin{array}{l}\text { Цикл фундаментальної, природничо- } \\
\text { наукової й загальноекономічної підготовки }\end{array}$ & Природничо-науковий цикл \\
\hline Третій & Цикл професійної і практичної підготовки & Професійний цикл \\
\hline
\end{tabular}

Для зручності далі в тексті цикли будуть називатися перший, другий, третій. Порівнюючи розподіл на цикли в досліджуваних стандартах, зауважимо, що в цьому випадку єдиною різницею $є$ визначення місця економічних дисциплін: в українському варіанті вони входять до другого циклу, російському - до першого. Кожен з циклів має нормативну та варіативну частини, співвідношення між якими визначає рівень академічної свободи навчального закладу. 
У стандартах використовуються різні підходи до визначення місця фізичної культури, практик і державної атестації: в Україні на «Фізичне виховання» виділяється 6 кредитів, проте це позакредитна дисципліна, хоча іï внесено до першого циклу. У Росії обсяг «Фізичної культури» - 2 кредити, які входять до загального навчального часу, але сама дисципліна не відноситься до жодного циклу. Подібна ситуація спостерігається 3 практиками. В українському стандарті бюджет навчального часу на навчальну i виробничу практики формуються за рахунок бюджету часу нормативної частини третього циклу, переддипломна - бюджету часу варіативної частини цього циклу. В російському варіанті практики не віднесені до певного циклу, бюджет часу визначається окремо. Бюджет навчального часу на державну атестацію в Україні формується за рахунок бюджету навчального часу варіативної частини, в Росії - виокремлюється. Тому ми визначили лише час теоретичного навчання і на цій основі зробили порівняння (див табл. 2).

Отже, під теоретичне навчання в Україні відводиться 231 кредит, в Росії - значно менше: 211-214 кредитів. Згадуючи загальну тенденцію до збільшення практичного навчання, можемо зауважити, що Росія вже робить певні кроки у цьому напрямі, Україні теж варто шукати резерв.

Найбільшу увагу вивченню дисциплін першого циклу відводиться у стандарті Російської Федерації: за бажання навчального закладу, ці дисципліни можуть складати до чверті від загального обсягу теоретичного навантаження. В Україні ця цифра значно менша. Українські навчальні заклади мають можливість четверту частину від загального обсягу навчального часу цього циклу віддати під варіативні дисципліни, російські близько $60 \%$.

Таблиия 2

\section{Порівняння розподілу навчального часу за циклами ОПП та ООП}

\begin{tabular}{|c|c|c|}
\hline Одиниці порівняння & ГСВО-Б, кредитів ЕСТS & $\begin{array}{ll}\text { ФДОС } & \text { ВПО-Б, } \\
\text { ЕСТS }\end{array}$ \\
\hline $\begin{array}{ll}\text { Перший цикл } \\
\text { У т.ч.: } & \\
- & \text { нормативна частина } \\
\text { - } & \text { варіативна частина }\end{array}$ & $\begin{array}{l}36(15,6 \%) \\
27(75 \%) \\
9(25 \%)\end{array}$ & $\begin{array}{l}50-55(23-26 \%) \\
22-27(40-54 \%) \\
23-33(46-60 \%)\end{array}$ \\
\hline $\begin{array}{ll}\text { Другий цикл } \\
\text { У т.ч.: } & \\
- & \text { нормативна частина } \\
\text { - } & \text { варіативна частина }\end{array}$ & $\begin{array}{l}36(15,6 \%) \\
27(75 \%) \\
9(25 \%)\end{array}$ & $\begin{array}{l}35-45(16-21 \%) \\
17-22(38-63 \%) \\
13-28(37-62 \%)\end{array}$ \\
\hline \begin{tabular}{ll}
\multicolumn{2}{l}{ Третій цикл } \\
У т.ч.: \\
- & нормативна частина \\
- & варіативна частина
\end{tabular} & $\begin{array}{l}159(69 \%) \\
57(35,8 \%) \\
102(64,1 \%)\end{array}$ & $\begin{array}{l}110-120(51-56 \%) \\
45-55(37,5-50 \%) \\
55-75(50-62,5 \%)\end{array}$ \\
\hline $\begin{array}{l}\text { Разом за циклами } \\
\text { У т.ч.: } \\
-\quad \text { базова частина } \\
-\quad \text { варіативна частина }\end{array}$ & $\begin{array}{l}231 \\
111(48 \%) \\
120(52 \%)\end{array}$ & $\begin{array}{l}211-214 \\
96-119(49-56 \%) \\
91-136(42,5-64 \%)\end{array}$ \\
\hline Фізична культура & 6 & 2 \\
\hline Практики & $9(3,8 \%)$ & $12-15(5-6 \%)$ \\
\hline $\begin{array}{l}\text { Державна атестація } \\
\text { У т.ч.: } \\
\text { Екзамен } \\
\text { Дипломна робота }\end{array}$ & $\begin{array}{l}1,5-16,5(0,6-6,9 \%) \\
1,5 \\
15 \text { (за умов вибору ВНЗ) }\end{array}$ & $\begin{array}{l}12(5 \%) \\
\text { На розгляд ВН3 } \\
12(5 \%)\end{array}$ \\
\hline Всього & 240 & 240 \\
\hline
\end{tabular}

Дисципліни другого циклу в українському варіанті представлені в тому ж обсязі, що й першого, але в Росії чомусь природничо-наукова підготовка студентів не розглядається як базова у процесі підготовки фахівців сфери туризму. Розробники українських стандартів, 
зрівнявши перші два цикли, таким чином притишили дискусії з приводу визначення пріоритетності гуманітарних чи природничих дисциплін у змісті професійної туристської освіти. Співвідношення між нормативними та варіативними частинами другого циклу встановлюється подібно до першого.

Третій цикл, цикл професійних дисциплін, є найбільшим за об'ємом: у ГСВО-Б йому виділяється до 70\% обсягу загального навчального часу, у ФДОС ВПО-Б - це трішки більше половини (до 56\%). На нашу думку, процес підготовки фахівця повинен бути більше орієнтованим на вивчення професійних дисциплін, тому в цьому випадку, український стандарт має перевагу перед російським. Що стосується співвідношення нормативних та варіативних частин, то в ГСВО-Б під базові дисципліни відводиться до 40\% навчального часу, в російському - не більше $50 \%$. Але вважати це перевагою вітчизняного стандарту складно, оскільки за відсутності ОКХ чим повинні керуватися навчальні заклади, наповнюючи варіативну частину, не зрозуміло.

Зупинимося на нормативній частині українського та російського стандартів. Цілком очевидно, що перелік дисциплін у досліджуваних країнах визначався залежно від різних чинників, тому вони значно відрізняються (див. табл. 3):

Таблиия 3

\section{Перелік навчальних дисциплін нормативної частини}

\begin{tabular}{|c|c|c|}
\hline Цикл & ГСВО-Б & ФДОС ВПО-Б \\
\hline Перший & $\begin{array}{l}\text {-Історія України } \\
\text {-Історія української культури } \\
\text {-Психологія } \\
\text {-Філософія } \\
\text {-Іноземна мова (за професійним } \\
\text { спрямуванням) } \\
\text {-Друга іноземна мова } \\
\text {-Українська мова (за професійним } \\
\text { спрямуванням) } \\
\text {-Фізичне виховання }\end{array}$ & $\begin{array}{l}\text {-Іноземна мова } \\
\text {-Фізична культура } \\
\text {-Російська мова та культура мови } \\
\text {-Філософія } \\
\text {-Історія Росії } \\
\text {-Основи соціальної держави }\end{array}$ \\
\hline Другий & $\begin{array}{l}\text {-Вища та прикладна математика } \\
\text {-Статистика } \\
\text {-Інформаційні системи та технології } \\
\text {-Економічна теорія } \\
\text {-Географія туризму } \\
\text {-Безпека життєдіяльності } \\
\text {-Екологія }\end{array}$ & $\begin{array}{l}\text {-Математика } \\
\text {-Інформатика } \\
\text {-Географія }\end{array}$ \\
\hline Третій & $\begin{array}{l}\text {-Рекреаційні комплекси } \\
\text {-Організація туризму } \\
\text {-Організація ресторанного господарства } \\
\text {-Організація готельного господарства } \\
\text {-Право } \\
\text {-Маркетинг } \\
\text {-Менеджмент } \\
\text {-Облік і аудит } \\
\text {-Економіка підприємства }\end{array}$ & $\begin{array}{l}\text {-Туристсько-рекреаційне проектування } \\
\text {-Організація туристської діяльності } \\
\text {-Інформаційні технології в туристській } \\
\text { індустрії } \\
\text {-Технології продаж } \\
\text {-Психологія ділового спілкування } \\
\text {-Людина та її потреби } \\
\text {-Іноземна мова (друга) }\end{array}$ \\
\hline
\end{tabular}

Провівши зіставлення переліку нормативних дисциплін, ми маємо визнати, що збігаються лише дисципліни першого циклу. Так, студенти обох республік вивчають історію власної країни, державну і дві іноземних мови, філософію і фізичну культуру. Незважаючи на однойменність напряму підготовки, всі інші дисципліни не збігаються. Ми не ставили за мету з'ясувати, що мали на увазі розробники вітчизняних стандартів, вносячи такі загальні назви дисциплін циклу професійної та практичної підготовки, як «Право», «Маркетинг», «Менеджмент» тощо, наголосимо, що забезпечити мобільність бакалаврів з туризму за таких умов досить складно. 
Розглянемо зміст підготовки фахівців сфери туризму в Україні та Росії за другим ступенем - магістр.

В Україні магістрів готують за спеціальністю «Туризмознавство», навчальний заклад має право обрати один із ії видів:

- $\quad$ Туризмознавство (туристична діяльність);

- $\quad$ Туризмознавство (туризм і рекреація);

- $\quad$ Туризмознавство (туризм і відпочинок).

- Н На нелогічності виокремлення даних профілів підготовки ми вже зупинялися [6, с.425]. У Російській Федерації підготовка магістрів здійснюється на півроку довше за однією з магістерських програмам:

- Інноваційні технології в туристській діяльності;

- $\quad$ Туризм та туристські ринки: глобальний, регіональний, національний;

- Загальна теорія туризму та туристської індустрії;

- Туризм: еволюція, структура, менеджмент, маркетинг;

- $\quad$ Анімація в туризмі;

- $\quad$ Екскурсійний сервіс Північно-Західної Росії;

- Організація та управління турбізнесом та ін..

Тематика магістерської програми визначається навчальним закладом і передбачає наявність публікацій у викладачів за цим профілем підготовки, відповідних навчальних та навчально-методичних матеріалів та необхідної навчально-матеріальної бази.

ГСВО-М передбачає формування двох циклів: 1) професійно орієнтованої гуманітарної та соціально-економічної підготовки; 2) професійної та практичної підготовки. ФДОС ВПО-М теж визначається два цикли: загальнонауковий та професійний. Тобто принципової різниці в підходах немає. ФДОС ВПО-М визначає співвідношення між теоретичним навчанням (перший та другий цикли) та практиками i (або) науководослідною роботою: остання складає 52-62 кредити зі 120, інші діляться між першим (2030 кредитів) та другим (30-40 кредитів) циклами. На підсумкову державну атестацію відводиться 3 кредити.

На відміну від них ГСВО-М указує лише мінімальний навчальний час за циклами: 6 кредитів у першому та 10,5 кредитів теоретичної і 12 - практичної підготовки в другому. Державна атестація (дипломна магістерська робота (проект)) складає 18 кредитів. У загальному обсязі практика та науково-дослідна робота українських магістрантів становить $30 \%$ від їхнього навчального навантаження, в той час як у російських - до $50 \%$.

Зміст підготовки магістрів туризму в досліджуваних країнах суттєво різниться. Виокремити однакові, подібні та відмінні дисципліни неможливо, оскільки всі визначені стандартами дисципліни різні (див. табл. 4).

Проаналізуємо наповнення нормативної частини освітніх програм кожного зі стандартів. У зв'язку з відсутністю в українських стандартах визначених компетенцій магістра туризму, розглянемо пропоновані для обов'язкового вивчення дисципліни, 3 позиції встановлених об'єктів діяльності: управління туристично-рекреаційними системами й інноваційними процесами; середній та вищий рівень управління в організаціях у сфері туризму; науково-педагогічна діяльність. На наш погляд, цим об’єктам діяльності відповідають лише дві з визначених дисциплін: «Методологія і організація наукових досліджень» та «Управління проектами в туризмі».

Уведення більшості інших дисциплін до нормативної частини видається нам нелогічним. Так, відповідно до Програми нормативних навчальних дисциплін [3, с. 9-17], курс «Міжнародне право»є коротким оглядом міжнародної правової системи, жодної згадки про туризм він не містить. Дисципліни «Інформаційні технології в туризмі» та «Управління якістю туристичних послуг», на наше глибоке переконання, в обов'язковому порядку повинні вивчатися ще бакалаврами; зміст курсу «Екскурсологія» (вимоги логіки до змісту i способу подання екскурсійного матеріалу; особистість і професійна майстерність екскурсовода тощо) теж відповідає завданням підготовки бакалавра. Цілком 
очевидно, що таке змістове наповнення нормативної частини ОПП підготовки магістра не сприяє розв'язанню кадрових питань вітчизняної індустрії туризму.

Таблиия 4

Перелік навчальних дисциплін нормативної частини

\begin{tabular}{|c|c|c|}
\hline Цикл & Україна & Росія \\
\hline ий & $\begin{array}{l}\text {-Інтелектуальна власність } \\
\text {-Міжнародне право } \\
\text {-Методологія і } \quad \text { організація } \\
\text { наукових досліджень } \\
\text {-Охорона праці } \quad \text { (за видами } \\
\text { економічної діяльності) }\end{array}$ & $\begin{array}{l}\text {-Теорія та методологія соціально- } \\
\text { економічних досліджень у туристській } \\
\text { діяльності } \\
\text {-Правове забезпечення діяльності в } \\
\text { туристській індустрії } \\
\text {-Комп'ютерні технології в науці та освіті } \\
\text {-Теорія та методологія рекреаційної } \\
\text { географії }\end{array}$ \\
\hline ий & $\begin{array}{l}\text {-Туризмологія } \\
\text {-Інформаційні технології в туризмі } \\
\text {-Управління якістю туристичних } \\
\text { послуг } \\
\text {-Міжнародний туризм } \\
\text {-Управління проектами в туризмі } \\
\text {-Екскурсологія }\end{array}$ & $\begin{array}{l}\text {-Організаційне проектування } \\
\text { управління проектами } \\
\text {-Технології туристсько-рекреаційного } \\
\text { проектування та освоєння території } \\
\text {-Прогнозування } \\
\text { туристської діяльності }\end{array}$ \\
\hline
\end{tabular}

Розробники російського стандарту, визначаючи області професійної діяльності магістра, взяли за основу область професійної діяльності бакалавра, доповнивши іiі проектуванням туристсько-рекреаційних зон та комплексів, управління ними. Усі визначені дисципліни нормативної частини відповідають майбутній області професійної діяльності, з одного боку, та забезпечують подальше формування наукового світогляду, 3 іншого. Для України цей стандарт може бути за зразок. Сдине, що на нашу думку, вимагає переосмислення, це введення курсу «Правове забезпечення діяльності в туристській індустрії» під час навчання за магістерською програмою, а не за бакалаврською.

3 іншого боку, росіяни могли б скористатися досвідом України та ввести до стандартів науково-аналітичну дисципліну, яка комплексно вивчає туризм задля прогнозування шляхів його подальшого розвитку. Як вона буде називатися - туристика, туризмологія чи туризмознавство - питання другорядне.

Отже, аналіз змісту підготовки фахівців із вищою професійною туристською освітою в Росії й Україні показав, що обидві країни ввели багатоступеневу вищу освіту: два ступені в першому випадку та три - в другому. В обох випадках підготовка здійснюється відповідно до державних стандартів, які встановлюють обсяг нормативної частини та їі зміст, зміст варіативної частини визначається навчальним закладом самостійно. Подібність спостерігається також у визначенні циклів підготовки та співвідношенні теоретичного та практичного навчання.

Різниця у процесі організації підготовки фахівців 3 вищою професійною освітою полягає, насамперед, у підході до визначення змісту освіти: в російському варіанті він визначається залежно від області та видів економічної діяльності майбутнього фахівця, в українському - довільно. Всі інші відмінності ми розглядаємо як наслідок відсутності освітньо-кваліфікаційних характеристик фахівців у вітчизняних стандартах.

Перспектива подальших досліджень полягає у визначенні моделі фахівця вітчизняного туристського ринку.

\section{Література}

1. Освітньо-професійна програма підготовки бакалавра напряму підготовки 6.140103 «Туризм» галузі знань 1401 «Сфера обслуговування» : ГСВО МОН України 6.140103-2010. - [Чинний від 2010-11-08]. - К. : ЦІНМВ КНТЕУ, 2010. - 16 с. 2. Освітньо-професійна програма підготовки магістра за спеціальністю 8.14010301 «Туризмознавство (за видами)» напряму підготовки 140103 «Туризм» галузі знань 1401 «Сфера обслуговування» : ГСВО МОН України 8.14010301-2010. - 
[Чинний від 2010-11-08]. - К. : ЦІІНМВ КНТЕУ, 2010. - 16 с. 3. Програми нормативних навчальних дисциплін підготовки магістрів за спеціальністю 8.14010301 «Туризмознавство (за видами)» напряму підготовки 140103 «Туризм» галузі знань 1401 «Сфера обслуговування». - К. : ЦІІНМВ КНТЕУ, 2010. - 75 с. 4. Федеральный государственный образовательный стандарт высшего профессионального образования по направлению подготовки 100400 Туризм (квалификация (степень) «бакалавр») - [Введен 2009-10-28]. - М., 23 с. 5. Федеральный государственный образовательный стандарт высшего профессионального образования по направлению подготовки 100400 Туризм (квалификация (степень) «магистр»). - [Введен 2009-1028]. - М., 23 с. 6. Щука Г. П. Критерії визначення спеціальностей та спеціалізацій в туристській освіті / Г. П. Щука // Географія і туризм: національний та міжнародний досвід : матеріали VI міжнародної наукової конференції (Львів-Розлуч, 5-7 жовтня 2012 р.). - Львів : Видавчничий центр ЛНУ ім. Івана Франка, 2012. - С. 424-428. 